IFAS Extension

\title{
Food Safety: FIVE STEPS TO FOOD SAFETY ${ }^{1}$
}

Jennifer Hillan $^{2}$

You can't see, smell, or taste bacteria, but they can be in and on your

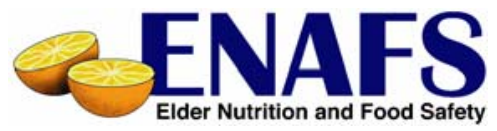
food! Follow these five steps to protect yourself and your family from food-related illness.

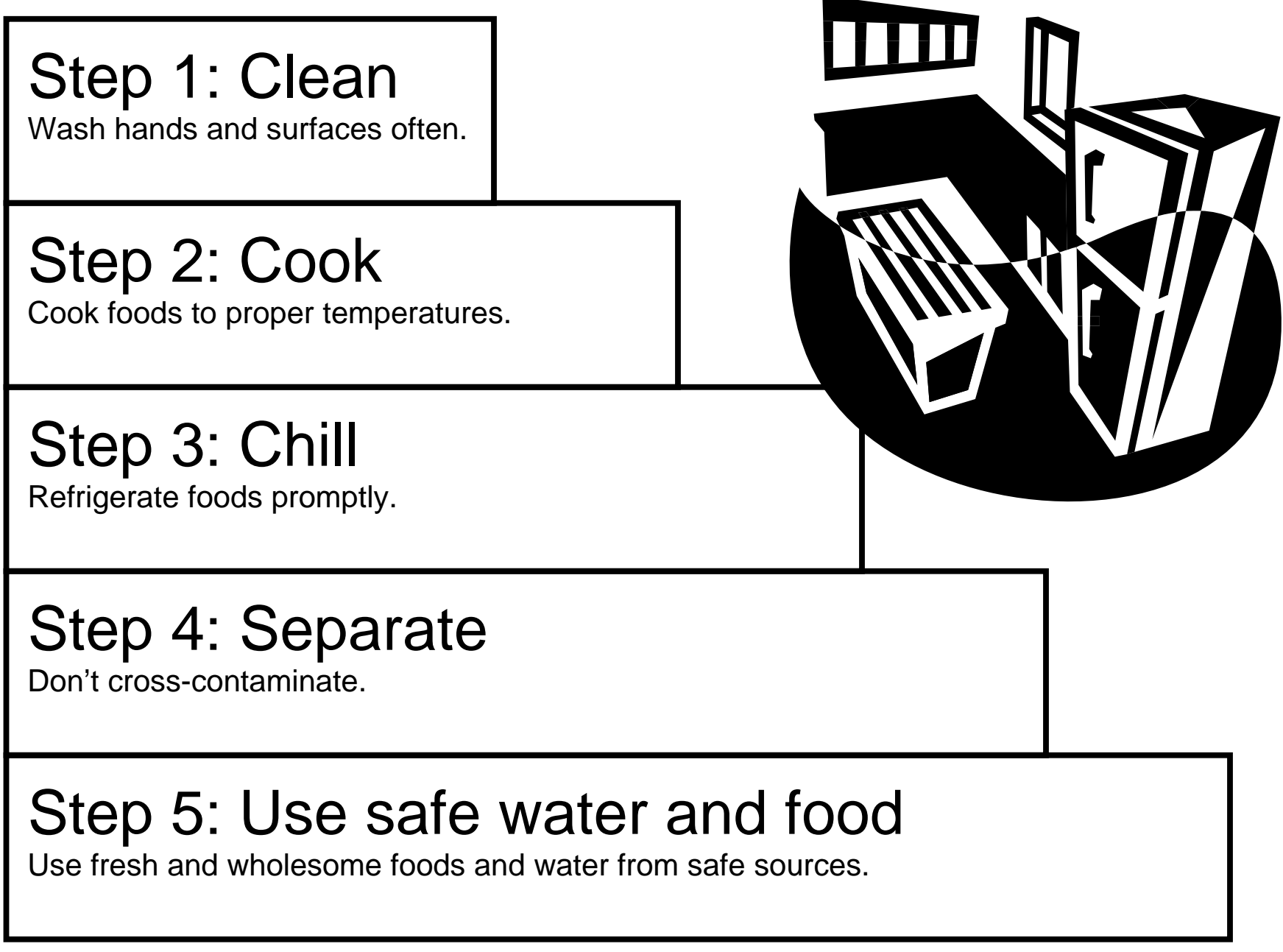

1. La versión en español de este documento es Cuidado de Alimentos: ¡Mantenga Seguros Los Alimentos! (FCS 8634Span).This document, FCS8634, is one in a series of the Department of Family, Youth and Community Sciences, Florida Cooperative Extension Service, IFAS, University of Florida, Gainesville, FL 32611. First published: February 2000. Revised August 2006. Please visit the EDIS Website at http://edis.ifas.ufl.edu.

2. Jennifer Hillan, MSH, RD, LD/N, ENAFS nutrition educator, Department of Family, Youth and Community Sciences, Florida Cooperative Extension Service, Institute of Food and Agricultural Sciences, University of Florida, Gainesville, FL 32611.

The Institute of Food and Agricultural Sciences (IFAS) is an Equal Opportunity Institution authorized to provide research, educational information and other services only to individuals and institutions that function with non-discrimination with respect to race, creed, color, religion, age, disability, sex, sexual orientation, marital status, national origin, political opinions or affiliations. For more information on obtaining other extension publications, contact your county Cooperative Extension service. U.S. Department of Agriculture, Cooperative Extension Service, University of Florida, IFAS, Florida A. \& M. University Cooperative Extension Program, and Boards of County Commissioners Cooperating. Larry Arrington, Dean. 